原著

高歯者の術後癒着性イレウスにおけるイレウス管留置の功罪

名古屋大学大学院病態制御外科学, 愛知県厚生連海南病院外科*

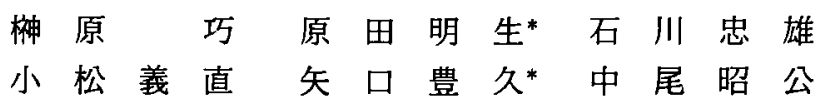

高齢者における後術瘁着性イレウスに対して, イレウス管留置の功罪について検討し た。術後痹着性イレウス症例234例で，イレウス管による保存的治療を行った 147 症例の うち，イレウス管造影を施行した97症例を年齢により75歳以上 (15症例)，75歳未満 (82 症例）に分けた。そして，発症からの経過時間，イレウス管の造影所見，進行状況，排 液量, 留置期間, 手術率, イレウス管留置中の合併症, 死亡率に着目して比較検討した。 高齢者群では非高齢者群に比してイレウス管の進行が不良であり, 排液量も遷延化する 傾向にあった，保存的治療継続中に合併症が有意に多く発症した $(\mathrm{P}<0.01)$. また保存 的改善となった高齢者群のイレウス管留置期間は有意に長かった $(\mathrm{P}=0.01)$. 高齢者の 術後痹着性イレウスにおいては, イレウス管の進行が緩慢で, 排液量が遷延化する傾向 にある．またイレウス管留置中に肺炎などの合併症をおこす危険も高く，保存的治療の 継続には柔軟な対応が必要である。

索引用語：術後瘾着性イレウス,イレウス管, 高齡者, 合併症

\section{緒言}

高齢者の術後瘾着性イレウスにおいては，判断の遅 れが致命傷になりうる。そこで適切な治療方針を決定 するため, 高齢者の術後瘾着性イレウスの特徵を, イ レウス管を留置した高齢者と非高齢者との相違に着目 して検討した。

\section{対象および方法}

1998年 4 月より2002年 9 月までに術後瘜着性イレウ スの診断で入院となった症例について検討した。なお 術後瘜着性イレウスは，開腹手術の既往がある小腸イ レウスで，他に原因病変が指摘できない症例を術後痹 着性イレウスと定義した，そのうち原疾患手術後，1 カ月以内の術後早期イレウス症例は, 疮着以外の種々 の要因の関与も考えられるため除外した。また，術後 痹着性イレウスと診断したが, 手術の結果, 癌の再発 など癒着以外の通過障害の原因が判明した症例（5 例)，炎症による腸管麻疸が主体で，通過障害の部位が 確認できなかった症例（2例）も除外した．当院で経

2005 年11月 2 日受付 2006 年 5 月31日採用

〈所属施設住所〉

干466-8560 名古屋市昭和区鶴舞町65
験した術後痹着性イレウス症例234例のうち67例は胃 管もしくは経過観察のみで保存的に改善, 20例は絞扼 が疑われ緊急手術となった.

検討にあたって,イレウス管を留置した残りの147例 を今回の対象とした.これらを，75歳以上の高齢者群 (24例) と，75歳未満の非高齢者群 (123例) に分けた. そして，1) 背景因子 (年齢構成, 性別, イレウスの 原因となった原疾患，，2）手術率，3) 手術内容, 術 中所見に着目して比較検討した.

次にイレウス管造影を施行した97症例（高齢者群： 15例, 非高齢者群：82例) (50症例はイレウス管造影せ ず抜去もし(は手術施行された。）について1)イレウ ス発症からイレウス管挿入までの経過時間，2）イレ ウス管の造影所見, 進行状況，3）排液量 4) 死亡率 に着目して比較検討した。

またイレウス管造影を施行した症例の中で，保存的 に改善した51症例（高齢者群：11例, 非高秢者群：40 例）においては，1) イレウス発症からイレウス管㨂 入までの経過時間，2) イレウス管の造影所見, 進行 状況，3）排液量，4）イレウス管留置中の合併症, 5 ) イレウス解除までに要したイレウス管留置時間に ついて比較検討した。 
表 1 患者背景と手術率

\begin{tabular}{|c|c|c|c|}
\hline & 高齢者群 (24例) & 非高齢者群 (123例) & $\mathrm{P}$ 值 \\
\hline 年齢 & $76.8 \quad(75-85)$ & $54.4(11-74)$ & \\
\hline 性別 ( $0^{x} /$ 早) & $11 / 13$ & $65 / 58$ & NS \\
\hline \multicolumn{4}{|l|}{ 原疾患 } \\
\hline 胃十二指腸 & 6 & 27 & \\
\hline 肝胆膵 & 2 & 5 & \\
\hline イレウス & 3 & 10 & \\
\hline 虫垂炎 & 3 & 23 & \\
\hline 大腸 & 3 & 25 & \\
\hline 婦人科 & 3 & 23 & \\
\hline その他 & 3 & 6 & NS \\
\hline 手術率 & $13(54 \%)$ & $42(3+\%)$ & NS \\
\hline
\end{tabular}

なお，イレウス管造影所見はガストログラフィン注 入 3 時間後のX線を参照したうえて，蜂須賀ら”に従 って，(1)小腸に閉塞を認めるもの，明らかな小腸の閉 塞は確認できないが造影胴の結腸への移行が認められ ないもの（小腸閉塞停滞型）(2)造影郕が結腸に移行す るもの（結腸移行型）に分類した。

また，イレウス管を挿入してから，48時間以降の先 端の位置が，X線上で挿入時と比較して $50 \mathrm{~cm}$ 以上進 行していた場合を進行良好と定義した。

2 群間の検定には $\chi^{2}$ test， t-test を用い，イレウス 管排液量の推移の検定にはANOVA を用いた。いず れも危険率0.05以下を有意差ありとした。

\section{結 果}

イレウス管を留置した 147 症例（高齢者群：24例， 非高齢者群：123例）による検討結果

\section{1. 背景因子に関する検討}

両群における年歯，性別，イレウスの原因となった 原疾患について示す（表 1 ）。平均年齢は高齢者群で 76.8 歳，非高齢者群で49.9葴であった。イレウスの原 因となった手術は高齢者群は胃癌，胃謴湯などに対す る上腹部手術が最多を占め, 非高齢者群は上腹部手術, 虫垂炎，大腸に対する手術，婦人科手術かほほ同頻度 であった。また，高齢者群における既往歴，併存疾患 について検討したが，24例中17例（70.8\%）がなんら 加の基礎疾患を有しており，心疾患 6 例，呼吸器疾患 3 例と心肺疾患の既往㰮が多くみられた。一方，非高 齢者群では123例中22例 (17.9\%) が併存疾患を有して いた（表 2 )。

\section{2。手術率に関する検討}

全身状態に著変がなければイレウス管留置後 5 日程 度は経過観察とし, 腹部理学的所見, X線所見, イレ
表 2 既往歴, 併存疾患

\begin{tabular}{l|c|c}
\hline & 高齢者群 (24例) & 非高齢者群 (123例) \\
\hline 心疾患 & $6(25.0 \%)$ & $5(4.1 \%)$ \\
高血圧 & $5(21.0 \%)$ & $8(6.5 \%)$ \\
呼吸器疾患 & $3(12.5 \%)$ & $3(2.4 \%)$ \\
脳血管障害 & $2(8.3 \%)$ & $2(1.6 \%)$ \\
椥呆 & $2(8.3 \%)$ & $0(0 \%)$ \\
糖尿病 & $2(8.3 \%)$ & $5(4.1 \%)$ \\
慢性督不全 & $1(4.1 \%)$ & $1(0.8 \%)$ \\
\hline
\end{tabular}

重複例あり

ウス管排液量の改善傾向がみられず，保存的治療の遷 延化が予測された場合に手術適応とした。手術移行症 例は高齢者群で13例 (54\%)，非高齢者群で43例(35\%) で両群に差は認めなかった（表 1 ）。

\section{3、手術結果に関する検討}

手術を行った56例（高齢者群：14例，非高龄者群： 42例）の術式は瘑着剥離術が34例（高齢者群：8例， 非高秢者群：26例)，小腸切除術が20例(高齢者群：5 例, 非高齢者群：15例), 吻合術が 2 例(高龄者群：1 例，非高齢者群：1 例) であった．全例において今回 のイレウスの原因となった閉塞部位を確認した．空腸 レベルでの閉塞が25例 (高齢者群：5例,非高齢者群： 20例)，回腸レベルでの閉塞が31例（高齢者群：8例， 非高齢者群：23例）でいずれも絞扼を認めない単純性 イレウスであった。手術内容, 術中所見で両群に差は 認めなかった。

イレウス管造影施行した 97 症例（高齢者群：15例， 非高齢者群：82例）による検討結果

\section{1．経過時間に関する検討}

両群におけるイレウス発症からイレウス管挿入まで の時間は差を認めなかった（高齢者群： $44.0 \pm 5.8 \mathrm{hr}$, 非高齢者群： $48.8 \pm 8.7 \mathrm{hr}$ ) (表 3 ).

\section{2.イレウス管造影, 進行状況に関する検討}

イレウス管造影所見においては，両群間に有意差は 認めなかったが, 高齢者群においては有意に進行状況 が不良であった $(\mathrm{P}=0.03)$ (表 3$)$.

\section{3. イレウス管排液量に関する検討}

非高齢者群の排液量は時間の経過とともに減少して いたが，高齢者群においては留置時からの排液量が非 高齢者に比して少なかった。さらに48時間以降も 400 $\mathrm{ml}$ 前後を推移しており遷延化する傾向にあった（表 3 , 図 1 ).

4，死亡率に関する検討 
表 3 イレウス管造影施行した高齢者群15例，非高龄者群82例の検討

\begin{tabular}{|c|c|c|c|c|}
\hline & & 高齢者群 (15例) & 非高歯者群 (82例) & $\mathrm{P}$ 值 \\
\hline \multicolumn{2}{|c|}{ ・発症からイレウス管挿入まての時間(時間) } & $44.0 \pm 5.8$ & $48.8 \pm 7.0$ & NS \\
\hline \multirow[t]{2}{*}{ ・イレウス管造影所見 } & 小腸閉塞停滞型 & 7 & 27 & \\
\hline & 結腸移行型 & 8 & 55 & NS \\
\hline \multirow{2}{*}{ ・イレウス管進行状況 } & 良好 & 7 & 61 & \\
\hline & 不良 & 8 & 21 & $P=0.03$ \\
\hline \multirow[t]{4}{*}{ ・イレウス管排液量 } & $(0 \sim 24)$ & $520.0 \pm 29.6$ & $881.0 \pm 46.4$ & \\
\hline & $(24 \sim 48)$ & $480.0 \pm 26.2$ & $545.7 \pm 16.9$ & \\
\hline & $(48 \sim 72)$ & $490.0 \pm 20.8$ & $302.4 \pm 30.0$ & \\
\hline & $(72 \sim 96)$ & $476.7 \pm 24.3$ & $286.0 \pm 29.2$ & $P<0.01$ \\
\hline • 死亡率 & & $2(13 \%)$ & $0\left(0^{\circ} \%\right)$ & $P<0.01$ \\
\hline
\end{tabular}

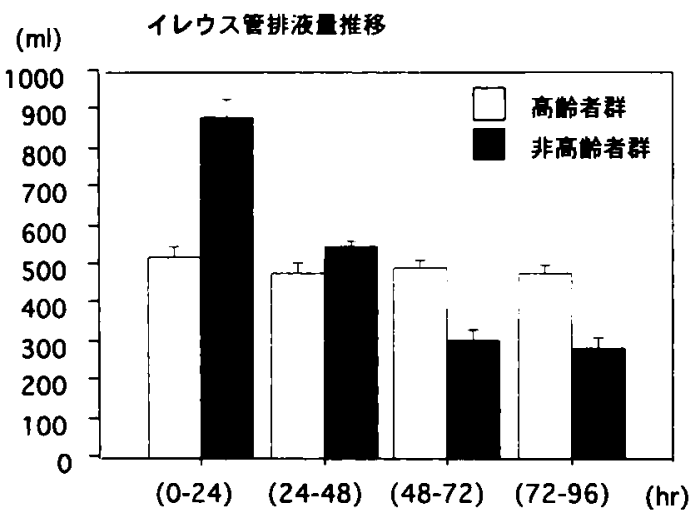

図 1 高齢者群 15 例と非高龄者群 82 例のイレウス管排 液量の推移

死亡例は 2 例でともに高龄者であった。1 例はイレ ウス管留置中に併発した肺炎が原因で死しし，1例は 敗血症にて死亡した．非高齢者群では死亡例はなかっ た $(\mathrm{P}=0.03)$ (表 3 ).

イレウス管留置後, 保存的に改善した 51 例(高齢者 群：11例，非高齢者群：40例）による検討結果

1. 経過時間に関する検討

両群の保存的改善例におけるイレウス発症からイレ ウス管挿入までの時間は差を認めなかった（高齢者群 保存的改善例: $33.8 \pm 1.5 \mathrm{hr}$, 非高齢者群保存的改善

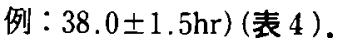

\section{2.イレウス管造影，進行状況に関する検討}

高齢者群保存的改善例においては, 小腸閉塞停滞型 が有意に多かった $(P=0.05)$ 。また高齢者群保存的改 善例においては有意に進行状況が不良であった（P= 0.04)(表 4 ).

\section{3. イレウス管排液量に関する検討}

非高齢者群保存的改善例の排液量は時間の経過とと
もに減少していたが，高齢者群保存的改善例において は48時間までの排液量が少なく $400 \mathrm{ml}$ 前後を推移して おり遷延化する傾向にあった（表 4, 図 2).

\section{4. イレウス管留置中の合阱症に関する検討}

保存的治療中の合併症は高齢者群で 6 例（5例：肺 炎, 1 例：敗血症) (25\%), 非高齡者群で 2 例(ともに 肺炎) ( $2 \%)$ であった $(\mathrm{P}<0.01)$ (表 4$)$.

\section{5，イレゥス管留置期間に関する検討}

イレウス管留置期間を 2 日以内，3〜4日，5 日以 上で分類した結果, 高齢者群の保存的改善例ではそれ ぞれ6例 (55\%)，2例 (18\%)，3例 (27\%) で非高 齢者群の保存的改善例では22例 (55\%), 11例 (28\%)， 7 例（18\%）だった.イレウス解除までに要した留置 時間は高齿者群の保存的改善例において有意に長加っ た(高齢者群保存的改善例: $76.4 \pm 13.7 \mathrm{hr}$, 非高齢者 群保存的改善例 : $49.8 \pm 5.8 \mathrm{hr})(\mathrm{P}=0.01)$ (表 4).

\section{考察}

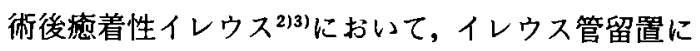
より,イレウスを解除させることが重症の症例でも可 能になっだ.しかしながら，高齢者における癒着性イ レゥスの治療に関しては意見がわかれる，高齢者は各 藏器の生理的な機能低下や予備能低下, 複数の併存疾 患が存在しているため, 手術決定時期が遅れると致死 的になりうるため，より慎重に治療方針を決定する必 要がある゙．これまで術後癒着性イレウスの治療方 針としては，胃管のみで経過観察とし，ガストログラ フィンによる消化管透視後, 軽快傾向がない場合には 早期に手術を推奨する方針と6) -10)，一般的には非高龄 者と同様にイレウス管を留置し $3 \sim 7$ 日の待機期間を 認める治療方針1)11ー18)がある．当院では術後瘾着性イ レウスの患者に対して腸管が CT 像上, 直径 $3 \mathrm{~cm}$ 以 上拡張している場合には，腸管の浮腫を最小限におさ 


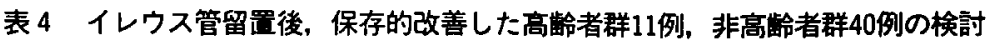

\begin{tabular}{|c|c|c|c|}
\hline & 高齢者群 (11例) & 非高齢者群 (40例) & $\mathrm{P}$ 值 \\
\hline • 発症からイレウス管挿入までの時間(時間) & $33.8 \pm 1.5$ & $38.0 \pm 1.5$ & NS \\
\hline \multirow{2}{*}{$\begin{array}{ll}\text { ・イレウス管造影所見 } & \begin{array}{l}\text { 小腸閉塞停滞型 } \\
\text { 結腸移行型 }\end{array}\end{array}$} & 3 & 0 & \\
\hline & 8 & 40 & $\mathrm{P}=0.05$ \\
\hline \multirow[t]{2}{*}{ ・イレウス管進行状況＼cjkstart良好 } & 5 & 31 & \\
\hline & 6 & 9 & $P=0.04$ \\
\hline \multirow[t]{4}{*}{ ・イレウス管排液量 } & $509.1 \pm 34.3$ & $844.8 \pm 71.3$ & \\
\hline & $454.5 \pm 24.7$ & $526.3 \pm 22.7$ & \\
\hline & $486.4 \pm 25.3$ & $245.0 \pm 45.0$ & \\
\hline & $468.2 \pm 30.4$ & $223.8 \pm 42.5$ & $P<0.01$ \\
\hline - 合併症（肺炎など） & $6(25 \%)$ & $2(5 \%)$ & $\mathrm{P}<0.01$ \\
\hline \multirow{4}{*}{$\begin{array}{c}5 \text { 日以上 } \\
\text { ・イレウス解除までに要した留置時間 }\end{array}$} & $6(55 \%)$ & $22(55 \%)$ & \\
\hline & $2(18 \%)$ & $11(28 \%)$ & \\
\hline & $3(27 \%)$ & $7(18 \%)$ & NS \\
\hline & $76.4 \pm 13.7$ & $49.8 \pm 5.8$ & $\mathrm{P}=0.05$ \\
\hline
\end{tabular}

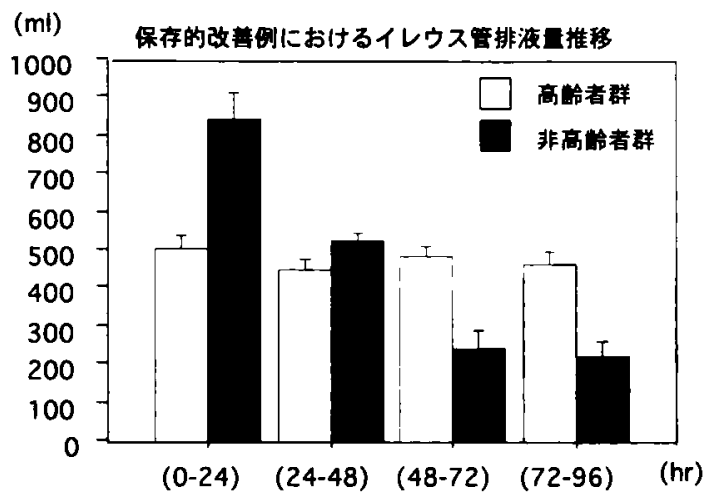

图 2 保存的改善となった高齢者群保存的改善症例 11 例と非高踚者群保存的改善症例 40 例のイレウス管排 液量の推移

える, bacterial translocation ${ }^{19201}$ の併発を防ぐなどの 理由から迅速なイレウス管留置を原則としている。さ らに 1 日のイレウス管排液量が $500 \mathrm{ml}$ に満たない場合 には必ず透視下でイレウス管先端位置が適切な位置に 留置されているかの再確認を行っている、イレウス管 を厳重に管理することにより，手術適応のある患者を より早い時期に決定することが可能と考えている211. 高齢者においても非高齢者と区別せず，積極的にイレ ウス管による保存的治療に努め手術を回避することを 目標にし, 術後瘾着性イレウスの治療を行っている.

今回の検討結果によると，高齢者においいては非高齢 者と比較して, 発症からの経過にほとんど差がなく, 術中所見における閉塞機転部位にも有意な差がないに もかかわらず，イレウス管の進行が緩慢で, 排液量が
遷延化する傾向にあった。また，高龄者のイレウス解 除には平均 $3 \sim 4$ 日というイレウス管留置期間を有す る（非高秢者は平均 2 日）という特徵があることが判 明した。さらに，今回のイレウス管造影施行した 97 症 例の検討では，イレウス管造影所見に有意な差を認め なかったが，減圧不十分のために造影せず手術へ移行 した高齢者群 9 例，保存的に改善したため造影せずイ レウス管を抜去した非高齢者群41例を検討に含めると 明らかに高齢者群では小腸停滞型が多い結果となっ た。これらの結果は, 高齢者は加齢による生理的変化 で慢性的に腸螦動が減弱していることが関与している と思われる。

高齢者において,イレウス管留置中に肺炎をおこし， 保存的にイレウス解除された後もその治療で難浩する 症例をたびたび経験した。死亡した 2 例も，入院時は 全身状態良好であったにもかかわらず，イレウス管留 置中に併発した肺炎，原因不明の敗血症が死亡原因と なっていた。早期に外科的治療へ移行すれば救命でき た症例であった。

今後も症例を重ねて,高齢者という特殊性を考慮し, 高齢者に発症した術後痹着性イレウスのより安全な治 療方針を確立したいと思う。

\section{結語}

高齢者は非高齢者に比してイレウス管の排液量が遷 延化する傾向にある．また，イレウス管留置中に肺炎 などの合併症を扝こす危険が高い，保存的治療の継続 には高齢者の術後痹着性イレウスの特徵を踏まえたう えで，慎重に対応する必要がある。 


\section{文献}

1）蜂須賀喜多男, 磯谷正敏：イレウスの保存的治療 とその限界. 消外 $14: 1639-1645,1991$

2) Alwan $\mathrm{MH}$, van Rij AM, Greig SF, et al: Postoperative adhesive small bowel obstruction: the resoueces impavts. N Z Med J 112 : 421-423, 1999

3) Gowen GF : Long tube decompression is successful in $90 \%$ of patients with adhesive small bowel obstruction. Am J Surg 185 : 512-515, 2003

4) Harris EA, Kelly AW, Pockaj BA, et al: Reoperation on the abdoment encased in adhesions. Am J Surg 184: 499-504, 2002

5）桶口道雄, 千見寺勝，奥井勝二他：術後痹着性1 レウス（とくに老年者について），日消外会誌 $9: 895-901,1976$

6）赤川高志, 山口晃弘, 磯谷正敏他：小腸機械的1 レウスの手術適応と術後成績. 日腹部救急医会誌 $19: 849-855,1999$

7) Biondo S, Pares D, Mora L, et al : Randomized clinical study of Gastrografin administration in patients with adhesive small bowel obstruction. Br J Surg $90: 542-546,2003$

8) Choi $\mathrm{HK}$, Chu KW, Law WL: Therapeutic value of gastrografin in adhesive small bowel obstruction after unsuccessful conservative treatment : a prospective trial. Ann Surg 236 : $1-6,2002$

9) Fleshner PR, Siegman MG, Slater GI, et al : A prospective, randomized traial of short versus long tube in adhesive small-bowel obstruction Am J Surg $170: 366-370,1995$

10) Aulin A, Sales JP, Barchar $S$, et al : Telebrix Gastro in the management of adhesive small bowel obstruction. Gastroenterol Clin Biol 29 : $501-504,2005$

11）恩田昌彦, 森山雄吉, 田中宣威他：イレウスに対 する保存的治療の限界。消外 $10 ： 1539-1548$, 1987

12）馬越正通, 渋谷哲男, 大場英己他：㽽着性イレウ ス手術のタイミング. 手術 $43: 919-924,1989$

13）冲永功太, 足達実樹, 白石賢子：㖹着性イレウス の保存的治療と手術のタイミング. 外科診療 $3: 335-342,1995$

14）松崎弘志，岡住慎一，高山 亘他：教室に招ける 街後イレウス症例の検討。千葉医誌 $77: 389-$ 393,2001

15）檜垣長斗, 浦 英樹, 秋山守文他：疮着性イレウ スにおける保存的治療，ロングチューブ減压療法 の限界と手術療法。日腹部救急医会誌 $19: 857$ 861,1999

16）村上雅彦，加藤博久, 草野满夫他：術後イレウス に対する各種チューブ減圧の選択とその手術適 応. 日腹部救急医会誌 $19: 863-868,1999$

17）進藤勝久：イレウスの保存的治療と手術の夕イミ ング. 臨外 $55: 189-192,2000$

18）加藤博久，村上雅彦，清水善徳他：術後瘾着性亿 レウスに対するチューブ療法の経験。日臨外会誌 $56: 16-21,1995$

19) Mainous MR, Ertel W, Chaudry IH, et al : The gut a cytokine-generating organ in systemic inflammation? Shock 4:193-199, 1995

20) O'Boyle CJ, MacFie J, Mitchell CJ, et al: Microbiology of bacterial translocation in humans. Gut $42: 29-35,1998$

21）榊原 巧, 原田明生, 石川忠雄他：痣着性イレウ スに対するイレウス管管理の重要性と手術時期の 検討，日消外会誌 38：1414-1419，2005 


\title{
CONSERVATIVE TREATMENT FOR ADHESIVE ILEUS IN THE AGED : ADVANTAGES AND DISADVANTAGES OF LONG TUBE PLACEMENT
}

\author{
Takumi SAKAKIBARA, Akio HARADA*, Tadao ISHIKAWA, \\ Yoshinao KOMATSU, Toyohisa YAGUCHI* and Akimasa NAKAO \\ Gastroenterological Surgery, Nagoya University Graduate School of Medicine \\ *Department of Surgery, Aichi Koseiren Kainan Hospital
}

In treating postoperative adhesive ileus in the aged patients, we tried to clarify the advantages and disadvantages of long tube placement. Of a series of 234 patients with adhesive ileus admitted to the hospital from April 1998 to September 2002, 147 patients received conservative treatment with long tube placement. Ninety-seven out of the 147 patients who received gastrografin follow-through study were classified into two groups according to the age : over 75 years $(n=15$; aged group) and under 75 ( $n=82$; younger group). The two groups were compared for the baseline chracteristics, characteristics of long tube management, operation rate, complications during long tube placement, and death rate. The drainage volume through a long tube decreased more clearly in the younger group, whereas in the aged group, the abdominal condition did not improve and the drainage volume of gastrointestinal juice was unchanging at a rate of more than $400 \mathrm{ml} /$ day. Significant differences were noted in the location of the tip of long tube and duration of long tube placement ( 76 vs. 45 hours) between the aged and younger groups. A significantly more patients $(25 \%)$ in the aged group developed complications during the conservative treatment $(\mathrm{P}<0.01)$.

In implementing conservative treatment for the aged patients, we should manage the long tube carefully to avoid complications such as pneumonia. This study provides a solid basis for the effective management of long tube placement in challenging cases of postoperative adhesive ileus in the aged patients. 